\title{
O'Connell Receives 2000 Inge Lehmann Medal
}

\section{PAGES 175,180}

\section{Richard J. O'Connell was awarded the Inge} Lehmann Medal at the AGU Fall Meeting Honors Ceremony, which was held on December 17, 2000, in San Francisco, California. The medal recognizes outstanding contributions to the understanding of the structure, composition, and dynamics of the Earth's mantle and core.

\section{Citation}

"Members of the Union, colleagues, ladies and gentlemen, and friends.

"Inge Lehmann was a highly inventive and creative scientist as a young woman and persisted in making outstanding contributions to geophysics, seismology, and Earth structure for over three-quarters of a century. At a time when there were few people in the field and almost no women, she was a singular example of quiet excellence. 1 often heard of her from Beno Gutenberg and Hugo Benioff. In honor of her contributions, the AGU established the Inge Lehmann Medal for 'outstanding contributions to the understanding of the structure, composition, and dynamics of the Earth's mantle and core.'The quality of an award is really determined by the excellence of the selection committee's nomination. They have made an excellent choice.

"Rick O'Connell was born in Helena, Montana, the son of a ranching family. I have known him since he arrived at Caltech in 1959 as a physics major. I had the privilege of working with him during his graduate studies where, well before he finished his Ph.D., he had completed a study on the viscosity of the Earth with Don Anderson (1967), and one with me on the dynamics of a phase change (MOHO) that was a whole volume of Reviews of Geophysics (1967). Rick had a combination of unusual traits: 1) a truly deep physical insight into geophysical problems; 2) the good taste to select very important, do-able problems; 3 ) the ability to carry through and to do an imaginative quantitative analysis without getting lost in the maze, while still respecting nature; and 4) an easygoing, gentle, generous character with good humor.

"Rick was a gentleman cowboy with excellent taste in good food and wines and an abiding interest in art (also with good taste). He did, in those early years, smoke a lot of my cigarettes; but would, after an extensive period of mooching, present me with a carton of cigarettes. Of all the vices enumerated above, the only one he gave up was smoking.

"During his years at Caltech, there was a wonderful comic strip by Stan Lynde called Rick O'Shay.This hero was the modest, gentle, but sharp-shooting, tough and just sheriff of a town in Montana called Conniption-a town of unruly, wild, unkempt inhabitants. Well, Rick O'Connell had his name changed-we all called him Rick O'Shay and he is still Rick O'Shay to me today.

"O'Connell's pioneering contributions and good taste in the field of geodynamics are world renowned as is his gentle and positive influence as a mentor and colleague of young people in geophysics and the Earth sciences in general. The committee has cited him: for his work on postglacial rebound; for determining that the whole mantle was subject to flow; for his model of the mantle flow associated with plate motions and subduction; for creating a model that globally predicted plate motions in which plate tectonics stir the upper mantle; and for the way he has connected geophysics with geochemistry.

"Madame President, it is a privilege and great personal delight for me to present to you Rick O'Connell, a scholar of great accomplishments and personal grace in a society of sometimes unruly inhabitants. As the recipient of the Inge Lehmann medal, he will, I trust, continue his contributions for the remainder of his $3 / 4$ of a century of science."-Gerald J.Wasserburg, California Institute of Technology, Pasadena, Calif., USA

\section{Response}

"Thank you, Jerry, for your generous and kind remarks.

"When 1 received the letter from John Knauss informing me that I had been awarded the Lehmann Medal, I was immensely surprised, pleased, and gratified. The study of the Earth's interior has been mostly the domain of seismologists, who are able to see into the deep Earth. I am pleased that this award has been given for work in geodynamics, and $\mathrm{I}$ am honored to represent those who work to relate the Earth's geologic history to the dynamics of the Earth's interior.

"Understanding how the Earth works and how the landscapes and seascapes we live in came about has always seemed to me to be an intellectual endeavor that can stand on its own merits, just as exploring the stars does. I have been lucky to be able to follow my interests throughout my life, pursuing understanding of how the Earth works.

"I grew up in Montana, where I had many opportunities to marvel at the magnificent mountains, valleys, and plains-occasionally while sitting on a horse as the Sun came up. Fortunately, my parents were supportive and allowed me to seek answers to how things worked, even at the risk of an explosion in my basement laboratory. They would have been especially gratified by this award.

"They also encouraged me to see a world beyond my father's ranch, and, prompted by

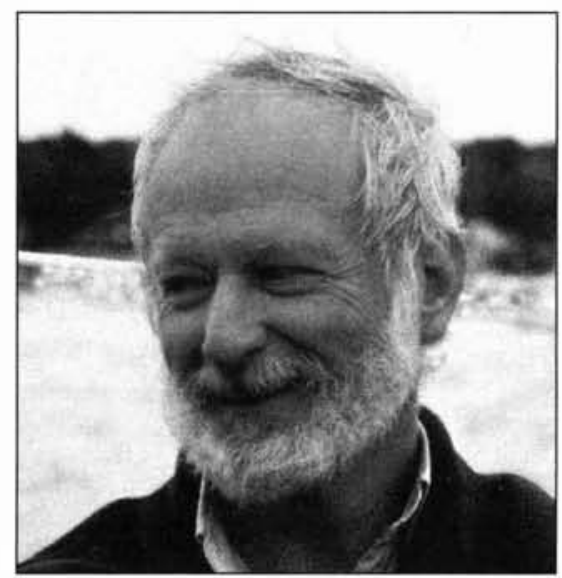

the first snowfall of September, I went to Caltech to study physics. There, Jerry Wasserburg showed me that studying the Earth was just another application of physics, and an unusually interesting one at that.

"Jerry later persuaded me to come back to graduate school at Caltech after I had taken a year off and seen a bit of the world. He showed me the difference between following curiosity and choosing the most promising problem to pursue. Jerry started me on a geodynamical problem-I later learned that the Moho is not a phase change, but I really learned how to construct a model to figure out what such a phase change would do. In the process, Jerry's broad interests and joy of doing science, and, I hope, a bit of his intellectual style, rubbed off on me.

"As a postdoc, I was again given the opportunity to follow new interests. I had previously worked on post-glacial rebound of the whole Earth, but Don Anderson (with Hartmut Spetzler's expert guidance) let me discover the fun of laboratory work, measuring high-pressure elastic properties and satisfying my desires to take things apart and then figure out how to put them back together.

"When Ray Siever recruited me to Harvard, 1 once again found opportunity, inspiration, and superb colleagues, both inside and outside the geology department. One day, Bernie Budiansky walked into my office, and I had the chance to explain geophysics to a firstrate intellect and a person who became a close friend. In return, he taught me mechanics and how to figure out the elastic properties of real rocks. In the mid-1970s, the dynamics of plate tectonics seemed the most important and challenging problem. A seminar with Geoff Davies and Brad Hager (among others) sent us all into geodynamics for good. At the same time,Adam Dziewonski started imaging lateral mantle structure, and the profound confluence of seismology and geodynamics really began.

"During one of those humbling momentsreading reviews of a proposal that didn't make it-I noted that one reviewer acknowledged that '.... at least the PI's students had done good work.' About that he was right; I have been lucky to work with outstanding students. Brad Hager was the first (I couldn't have had a better one), and I now interact 
with his academic progeny, through several generations; I continue to learn from my current students. Throughout my career I have always tried to give my students the same encouragement and freedom to pursue their interests that I have had. As was said about a young Julian Schwinger, "The best guidance for such outstanding students is to leave them to their own devices.'

"I am lucky to have the love and understanding - and forbearance — of my family, and I am extremely pleased that they are here tonight. My son Brian is here with his wife Claudia. He has been with me from Caltech to Harvard, with meetings and sabbaticals in between. He has always been a source of good humor, sense, and perspective, and an inspiration for going through life and overcoming difficulties with grace. My wife Susan has good-naturedly adapted to sharing a life with a scientist who is frequently distracted and has horrible work habits. She also taught me about sailing on Buzzards Bay and makes my life more fun than it deserves to be My stepdaughter Lily shared my commute for several years; I miss her company and the new perspective she brought me.

"I've been lucky in my opportunities and in having support from those who allowed and encouraged me to pursue them, as well as in having good colleagues and good students. They all share this award."-Richard J. O'Connell, Harvard University, Cambridge, Mass., USA

\section{Roederer Receives 2000 Edward A. Flinn III Award}

\section{PAGES 175,177}

Juan G. Roederer was given the Edward A. Flinn III Award at the AGU Fall Meeting Honors Ceremony, which was held on December 17,2000 , in San Francisco, California. The award recognizes those individuals who personify the Union's motto, "unselfish cooperation in research," through their facilitating, coordinating, and implementing activities.

\section{Citation}

"It is in every scientist's best interest to work in a field that is strong, vibrant, and productive, but fields do not evolve in this way by themselves. They need a critical mass of talented individuals working, even if competitively, toward a common goal, and they need infrastructure. Someone has to take the lead, to sacrifice his or her personal time to serve the common good, or that enabling infrastructure will not be put in place. I call the realization of this need 'altruistic self-interest.' It is the principle that underlies AGU's motto 'Unselfish Cooperation in Research.' It is the reason we should freely exchange data and ideas with our colleagues, and it has been a motivating principle for Juan Roederer in his organization of national and international programs for over three decades.

"Few scientists understand the principle of altruistic self-interest and even fewer live by it, but Juan Roederer is one of those few. As vice president and then president of the International Association of Geomagnetism and Aeronomy in the 1970s, he reorganized and revitalized IAGA, so that today it is arguably the most active of IUGG's associations. Roederer was the force behind the International Magnetospheric Study from 1976 to 1978, which mounted the first coordinated attack on the physics of the Earth's magnetosphere. He was one of the early organizers of the Global Change program. He initiated the Geospace Environment Modeling program that, with NSF support, has successfully coordinated four campaigns to address critical issues in the Earth's magnetosphere. He was the international coordinator of ICSU's SolarTerrestrial Energy Program from 1990 to 1997. Back at home, Roederer led the world-renown Geophysical Institute of the University of Alaska at Fairbanks from 1977 to 1986 ; he helped draft the Arctic Research and Policy Act passed by Congress in 1984 . He served as vice chairman and then chairman from 1985 to 1991 of the U.S.Arctic Research Commission, publishing numerous articles and monographs on arctic research policy; and from 1984 to 1992, he served as AGU's international secretary. He has accomplished all that while contributing significantly to the fields of space physics, the psychoacoustics of music, and international science policy.

"Juan Roederer was born in Trieste, Italy, on September 2, 1929; moved to Vienna as a child; and then emigrated to Argentina in 1939. He completed his education with a doctorate in physical-mathematical sciences from the University of Buenos Aires in 1952, in which he studied latitudinal variations of cosmic rays along the Andes at altitudes from sea level to 6000 meters. After 2 years of research at the Max-Planck-Institut in Göttingen, Germany, he returned to an assistant professorship at the University of Buenos Aires and was appointed chief of the Cosmic Ray Laboratory of the Argentine Atomic Energy Commission. During this period, as part of a 5 -member commission, he helped reorganize the 90,000 student university, establishing full-time professorships and graduate schools that did not exist before then, and making research accomplishments a condition of faculty promotion. In 1959, he became a full professor and director of the National Cosmic Ray Center. Over the next several years, the Argentine Cosmic Ray Center established three world-class cosmic ray observatories in Argentina, operated an Antarctic observatory, flew long-duration stratospheric balloons, and launched sounding rockets.

"After a 2-year appointment as an NRC senior research fellow at the Goddard Space Flight Center, he returned to Buenos Aires in June 1966 to be confronted with a military coup. After a period of unsuccessful protest over the military interference in university affairs, he and his family took the opportunity, when it was presented to them, to emigrate to the U.S., joining the physics faculty at the University of Denver in 1967. From 1977 to 1986 , he served as director of the Geophysical Institute of the University of Alaska, after which he returned to teaching physics until his retire-

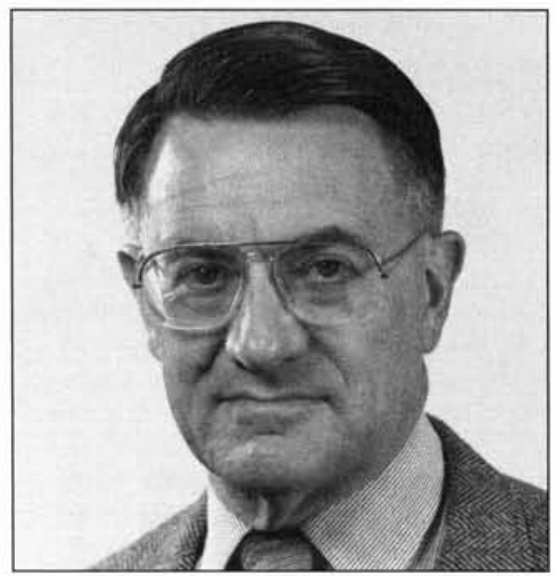

ment in 1993. Since then he has continued to conduct research as an emeritus professor at the University of Alaska.

"For a career of significant service to the geophysical communities of two nations and an equally great contribution to the international community, it is in our interest to honor Juan Roederer with the Flinn Award, both to thank him for his efforts and also to encourage others to serve the community as he has."-C.T.Russell, University of California, Los Angeles, USA

\section{Response}

"When a scientist retires, he/she often finds him/herself writing autobiographies and reminiscences and being interviewed for oral history accounts. As a by-product of this activity comes the self-evaluation of one's own contributions to science.

"When I started pondering about this 'legacy thing,' I began to realize that, indeed, much of my professional life was dedicated not to analyzing data or developing theories, not to publishing papers, not to writing proposals, or, as a science administrator, not to running after short-term pork barrel money; but, instead, to helping develop long-term research plans and policies for the community.

"Why did I do this? Why did I so often give up opportunities for research, only to sit on some 'obscure'committees? The explanation may be found with the experiences during the early times in my life, as a fledgling physicist in the mid-1950s in Argentina. This was then a developing country that had just come out of a long dictatorship, with neither organized research nor full-time professorships at its universities, no 